\title{
ОСОБЛИВОСТІ СУБ'ЄКТИВНОГО КОНТРОЛЮ У ЕМІГРАНТІВ ТА РЕЕМІГРАНТІВ, ХВОРИХ НА ДЕПРЕСИВНІ РОЗЛАДИ
}

\author{
ДВНЗ «Тернопільський державний медичний університет ім. І.Я. Горбачевського МОЗ України»,
} м. Тернопіль, Україна

\begin{abstract}
Мета: вивчення особливостей суб'єктивного контролю у емігрантів та реемігрантів, хворих на депресивні розлади.
Матеріали і методи. За допомогою запитальника «Рівень суб'єктивного контролю» та методики вивчення ціннісних орієнтацій було обстежено 585 хворих на депресивні розлади.

Результати. Проведене дослідження особливостей суб'єктивного контролю у 196 емігрантів, 191 реемігрант у порівнянні з 198 не емігрантами, хворими на різні фрорми депресивних розладів, встановило більшу виразність загальної інтернальності у емігрантів та меншу - у реемігрантів. При цьому у ключових сферах досягнень, сімейних відносин, трудових відносин, міжособистісних відносин емігранти виявляють ознаки інтернальності, а реемігранти екстернальності. Натомість реемігрантам притаманний інфрернальний тип суб'єктивного контролю у сфері невдач. Виявлені закономірності можуть бути пояснені як соціально-психологічними особливостями, так і особистісними характеристиками емігрантів та реемігрантів. Найбільш виразні розбіжності виявлені у хворих на психогенні депресивні розлади, меншою мірою вони виявляються у хворих на ендогенні та органічні депресії. Причини виявлених особливостей можуть полягати як в особистісних особливостях емігрантів та реемігрантів, так і у впливі об'єктивних соціально-психологічних фракторів.
\end{abstract}

Висновки. Виявлені закономірності повинні враховуватися при розробці лікувально-реабілітаційних та профрілактичних заходів.

КЛЮчОВІ СЛОВА: емігранти, реемігранти, депресивні розлади, суб'єктивний контроль.

Проблема еміграції та рееміграції в Україні входить до числа найбільш актуальних державних та суспільних проблем. Еміграція є одним з наймасовіших соціальних процесів у світі, який останніми роками виявляє очевидну тенденцію до зростання. Кількість українських мігрантів оцінюється у 6,5-7 млн осіб, однак, з урахуванням значної кількості нелегальних мігрантів, ці дані можуть бути значно заниженими [3;7]. Самостійну соціальну, медико-психологічну та психіатричну проблему являє собою рееміграція, масштаби якої порівнянні 3 масштабами еміграції. Водночас, при значній соціальній та медичній значущості проблеми еміграції та рееміграції в Україні, її дослідженню та вирішенню не приділяється належної уваги.

Депресивні розлади є однією з найпоширеніших та небезпечних психічних патологій. Міграція з сучасних наукових позицій розглядається як один із фракторів, що негативно впливає на стан психічного здоров'я, спричинює трансформацію особистісного реагування та дезадаптацію особистості, провокує маніфестацію або екзацербацію ендогенних психічних захворювань [8-9]. Рядом досліджень встановлено наявність негативних особистісних змін, асоційованих з міграцією: емоційної нестійкості, тривожності, фррустрованості, психічної дезадаптації, депресивних розладів [1;2;4;6].

Виходячи з цих положень, метою цього дослідження було вивчення особливостей суб'єктивного контролю у емігрантів та реемігрантів, хворих на депресивні розлади.

Дане дослідження $€$ фрагментом наукової дослідницької роботи «Депресивні розлади у емігрантів та реемігрантів (клініко-психопатологічні та патопсихологічні ососбливості, сучасні підходи до лікування та реабілітації)», окремі результати якої уже публікувалися.

Матеріали і методи. Обстеження проводилося за допомогою запитальника «Рівень суб'єктивного контролю» [5]. Обстежено 196 осіб, які щонайменше протягом останнього року проживали за межами України і планували найближчим часом повернутися за кордом (емігранти); 191 особу, яка не менше року проживала за межами України і протягом останнього року повернулася для постійного проживання в Україну (реемігранти); 198 осіб, які постійно проживають в Україні і ніколи не виїжджали за її межі для тривалого проживання (не емігранти). Усі обстежені хворі перебували на лікуванні у Тернопільській обласній психоневрологічній лікарні за період 2010-2014 років, їм був встановлений остаточний клінічний діагноз депресивного розладу відповідно до критеріїв MKX-10. Психогенні депресивні розлади (коди за МKX-10 F43.21 та F43.22) встановлені у 69 не емігрантів, 68 емігрантів та 67 реемігрантів, ендогенні (коди за MKX-10 F31.3, F31.4, F32.1, F32.2, F33.1 та F33.2) - відповідно у 65, 66 та 63 осіб, органічні 
(код за МKX-10 F06.3) - відповідно у 64, 62 та 61 осіб; розбіжності між групами незначущі.

Статистичний аналіз результатів проводився за допомогою непараметричного тесту Манна-Вітні.

Результати дослідження та їх обговорення. Наукові дані щодо особливостей психологічної сорери емігрантів та реемігрантів, хворих на різні форми депресій, є вкрай недостатніми. Виходячи з цього, ми дослідили особливості суб'єктивного контролю емігрантів та реемігрантів, хворих на психогенні, ендогенні та органічні депресивні розлади. Дослідження особливостей суб'єктивного контролю у різних ссрерах $€$ важливим компонентом вивчення мотиваційного компоненту еміграції. Концепція специсрічного типу особистості, асоційованого з еміграцією (яка, втім, має як прихильників, так і супротивників), передбачає також певні особливості мотиваційної сфери та стану суб'єктивного контролю мігрантів. У цьому зв'язку дослідження особливостей внутрішнього суб'єктивного контролю у емігрантів та реемігрантів, хворих на депресивні розлади, має важливе значення як для встановлення особистісних особливостей емігрантів та реемігрантів, так і для розуміння патогенетичних механізмів, які лежать в основі виникнення різних фрорм депресивних розладів у цієї категорії осіб.

Основу дослідження суб'єктивного контролю у нашому дослідження складало вивчення інтернальності. В аспекті концепції локусу контролю Д. Роттера інтернальність $€$ індикатором ступеня суб'єктивного контролю як особистісної характеристики, що описує те, якою мірою людина відчуває себе активним суб'єктом власної діяльності, а в якій - пасивним об'єктом дії інших людей і зовнішніх обставин. Використана нами методика дозволяє визначити як загальну інтернальність, так і інтернальність в окремих сорерах - досягнень, невдач, сімейних відносин, трудових відносин, міжособистісних відносин, здоров'я і хвороби.

При дослідженні суб'єктивного контролю у емігрантів та реемігрантів, хворих на психогенні депресивні розлади, були виявлені важливі закономірності. При аналізі загальної інтернальності було встановлено, що емігрантам притаманний високий рівень інтернальності. Це єдина група, у якій середній рівень загальної інтернальності перевищує рівень у 5,5 стена, що відповідає інтернальному типу контролю. У емігрантів рівень загальної інтернальності склав 6,04ะ1,57 стена, що свідчить про високий рівень суб'єктивного контролю над будь-якими значущими ситуаціями. Таким людям властиве переконання, що більшість важливих подій у їхньому житті є результатом їхніх власних дій, що вони можуть ними керувати і, отже, відчувають свою власну відповідальність за ці події і за те, як складається їхнє життя в цілому. Натомість реемігрантам притаманний низький рівень загальної

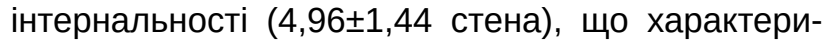
зує низький рівень суб'єктивного контролю. Таким особам властива відсутність бачення зв'язку між власними діями і значущими для них подіями життя, вони не вважають себе здатними контролювати власне життя і впевнені, що більшість подій у ньому $є$ результатом випадкового збігу обставин або дій інших людей. Не емігранти за рівнем суб'єктивного контролю займають проміжну позицію; їх показник наближений до середнього рівня (5,42 $\pm 1,59$ стена). Значущі розбіжності за рівнем загальної інтернальності виявлені при порівнянні груп емігрантів та не емігрантів ( $p=0,027)$, реемігрантів та не емігрантів ( $p=0,089)$, емігрантів та реемігрантів $(p=0,001)$.

Аналіз особливостей суб'єктивного контролю в сорері досягнень виявив іще суттєвіші розбіжності між емігрантами, реемігрантами та не емігрантами. Так, у емігрантів середній рівень інтернальності в цій сорері склав 6,78+1,74 стена; це найвищий показник серед усіх груп, він відповідає високому рівню суб'єктивного контролю над емоційно позитивними подіями і ситуаціями, переконанню, що вони самі домагаються успіхів у житті, а також здатні успішно досягати успіхів у майбутньому. Реемігрантам, навпаки, притаманний низький рівень

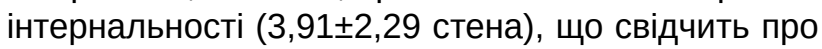
схильність приписувати свої успіхи, досягнення і радості зовнішнім обставинам - удачі, щасливій долі або допомозі з боку інших людей. У не емігрантів показник інтернальності в сорері досягнень був у межах середніх значень $(5,42 \pm 2,46$ стена). Значущі розбіжності виявлені при порівнянні груп емігрантів та не емігрантів $(p=0,001)$, реемігрантів та не емігрантів ( $p=0,001)$, емігрантів та реемігрантів $(p=0,001)$.

Зворотною є картина суб'єктивного контролю в сорері невдач. Тут найвищий показник виявлений у реемігрантів $(5,94 \pm 2,44$ стенів), дещо нижчий

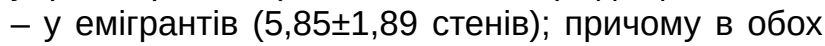
групах він перевищує середній рівень у 5,5 стена. Це свідчить про розвинене почуття суб'єктивного контролю по відношенню до негативних подій і ситуацій, що виявляється у схильності звинувачувати себе у різноманітних невдачах, неприємностях і стражданнях. У не емігрантів рівень інтернальності в сорері невдач складає 5,28 2,31 стена, що відповідає середньому рівню. Значущі розбіжності виявлені при порівнянні груп емігрантів та не емігрантів ( $p=0,080)$.

Результати аналізу суб'єктивного контролю у сорері сімейних відносин свідчать про високий рівень інтернальності у емігрантів $(6,24 \pm 1,32$ стена). Такі індивіди вважають себе відповідальними за події власного сімейного життя. У реемігрантів виявлений низький рівень інтернальності у сімейних

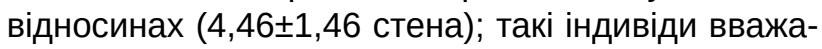
ють не себе, а своїх партнерів причиною значущих 
ситуацій, що виникають у їхніх родинах. У не емігрантів рівень інтернальності в сімейних відноси-

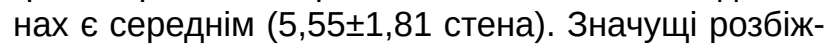
ності виявлені при порівнянні груп емігрантів та не емігрантів ( $p=0,025)$, реемігрантів та не емігрантів $(p=0,001)$, емігрантів та реемігрантів $(p=0,001)$.

Меншою мірою виражені розбіжності в інтернальності у сорері трудових відносин. Емігрантам загалом притаманний більш високий рівень

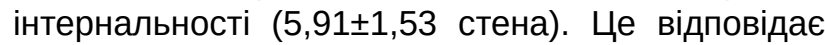
переконанню індивіда у тому, що його дії $€$ важливим фрактором в організації власної виробничої діяльності, у відносинах в колективі та у просуванні службою. При цьому у реемігрантів та не емігрантів також виявлений доволі високий рівень інтернальності, хоча й менший, ніж у емігрантів

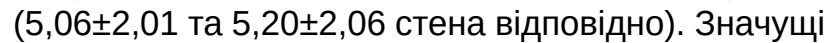
розбіжності виявлені при порівнянні груп емігрантів та не емігрантів ( $p=0,058)$, емігрантів та реемігрантів ( $p=0,018)$.

У сорері міжособистісних відносин найвищий рівень суб'єктивного контролю виявлений у

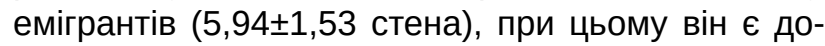
волі високим також у реемігрантів та не емігрантів

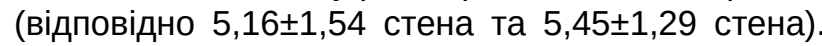
Високий показник за цією сорерою свідчить про те, що індивід вважає себе спроможним контролювати свої неформальні відносини з іншими людьми, викликати до себе повагу і симпатію тощо. Значущі розбіжності виявлені при порівнянні груп емігрантів та не емігрантів ( $p=0,073)$ та емігрантів й реемігрантів ( $p=0,014)$.

Інша картина виявлена при аналізі особливостей внутрішнього контролю щодо здоров'я і хвороби: найвищий рівень інтернальності у цій сорері

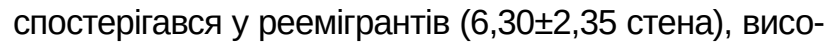
кий - у не емігрантів $(5,80 \pm 2,41$ стена), найменший у емігрантів (5,26 $\pm 2,90$ стена). Високі показники свідчать про те, що індивід вважає свій спосіб життя багато в чому відповідальним за своє здоров'я, у хворобі схильний звинувачувати самого себе і вважати, що одужання багато в чому залежить від його дій. Значущі розбіжності виявлені при порівнянні груп емігрантів та реемігрантів $(p=0,038)$.

У емігрантів та реемігрантів, хворих на ендогенні депресивні розлади, загальні закономірності, виявлені у хворих на психогенні депресії, зберігаються, однак виразність їх $€$ меншою. Так, середній рівень загальної інтернальності у емігрантів становив 5,77士1,50 стена, що відповідає інтернальному типу суб'єктивного контролю, а у

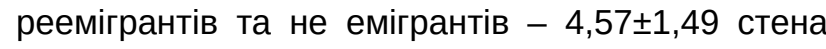

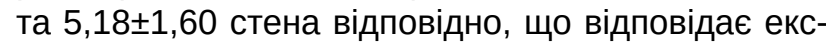
тернальному типу суб'єктивного контролю. Значущі розбіжності виявлені при порівнянні рівнів загальної інтеральності між групами емігрантів та не емігрантів ( $p=0,048)$, реемігрантів та емігрантів $(p=0,036)$, емігрантів та реемігрантів $(p=0,001)$.
У сорері досягнень найвищий рівень суб'єктивного контролю виявлений у емігрантів (6,23 2,19 стенів), найнижчий - у реемігрантів (3,95 $\pm 2,04$ стенів); у не емігрантів рівень інтернальності у сорері досягнень

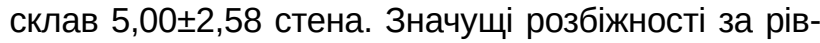
нями інтернальності у цій сфері виявлені при порівнянні груп емігрантів та не емігрантів ( $p=0,004)$, реемігрантів та не емігрантів $(p=0,031)$, емігрантів та реемігрантів ( $p=0,001)$.

У сорері невдач найвищий рівень суб'єктивного контролю виявлений у реемігрантів $(6,52 \pm 2,28$ стенів), менший - у емігрантів (6,06 $\pm 2,15$ стенів)

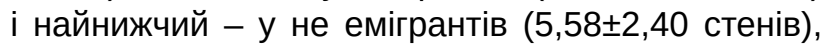
однак в усіх групах показник відповідає інтернальному типу суб'єктивного контролю. Значущі розбіжності виявлені при порівнянні груп реемігрантів та не емігрантів ( $p=0,022)$.

Дещо інша картина виявлена при аналізі особливостей суб'єктивного контролю у сорері сімейних відносин. Інтернальний тип контролю виявлений у емігрантів $(5,95 \pm 1,43$ стена), екс-

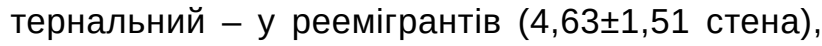
у не емігрантів показник свідчить про відсутність чіткої тенденції до інтернальності та екстер-

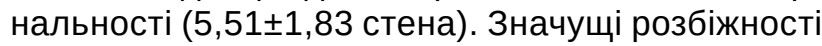
виявлені при порівнянні груп реемігрантів та не емігрантів $(p=0,004)$, емігрантів та реемігрантів $(p=0,001)$.

У сорері трудових відносин найвищий рівень суб'єктивного контролю виявлений у емігрантів $(5,98 \pm 1,52$ стена), найнижчий - у реемігрантів $(4,71 \pm 2,23$ стена); показники у не емігрантів

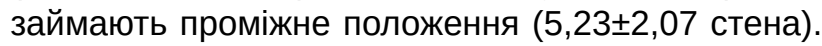
Значущі розбіжності за цією сорерою виявлені при порівнянні груп емігрантів та не емігрантів $(p=0,046)$, реемігрантів та емігрантів $(p=0,002)$.

Найвищий рівень суб'єктивного контролю у сорері міжособистісних відносин виявлений у емі-

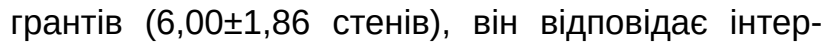
нальному типу. У реемігрантів та не емігрантів рівень інтернальності нижчий і відповідає екстер-

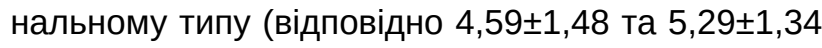
стена). Значущі розбіжності виявлені при порівнянні груп емігрантів та не емігрантів ( $p=0,009)$, реемігрантів та не емігрантів $(p=0,005)$, емігрантів та реемігрантів ( $p=0,001)$.

Особливістю суб'єктивного контролю щодо здоров'я і хвороби у хворих на ендогенні депресивні розлади $є$ екстернальний тип контролю у всіх досліджених груах: найнижчий - у реемігран-

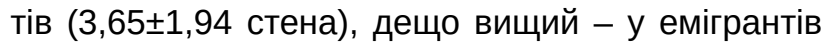

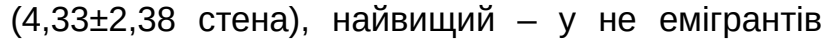
(4,74 2,29 стена). Низькі показники інтернальності у цій сорері свідчать про пасивне ставлення до власного здоров'я і хвороби: такі індивіди вважають здоров'я і хворобу результатом дії зовнішніх факторів і сподіваються на те, що одужання прийде в результаті дії інших людей, насамперед ліка- 
рів. Значущі розбіжності виявлені при порівнянні груп реемігрантів та не емігрантів $(p=0,009)$.

Особливості суб'єктивного контролю у емігрантів та реемігрантів, хворих на депресивні розлади органічного ґенезу, загалом збігаються з тими, що притаманні хворим на ендогенні депресії, однак мають і певні особливості. Так, інтернальний тип суб'єктивного контролю виявлений у емігрантів

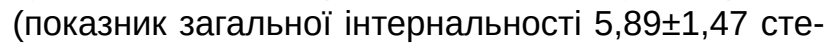
на), екстернальний - у реемігрантів $(4,59 \pm 1,5$ стена), проміжний (ближче до екстернального) - у не

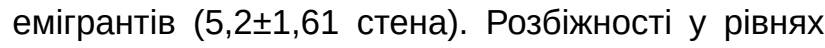
загальної інтернальності значущі при порівнянні усіх груп: емігрантів та не емігрантів $(p=0,023)$, реемігрантів та не емігрантів ( $p=0,038)$, емігрантів та реемігрантів $(p=0,001)$.

Інтернальний тип суб'єктивного контролю у сорері досягнень виявлений у емігрантів $(6,45 \pm 1,91$ стенів), екстернальний - у реемігрантів та не емі-

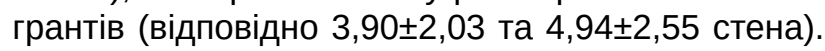
Значущі розбіжності виявлені при порівнянні груп емігрантів та не емігрантів $(p=0,001)$, реемігрантів та не емігрантів $(p=0,032)$, емігрантів та реемігрантів ( $p=0,001)$.

У сорері невдач усі три групи обстежених хворих виявляють інтернальний тип суб'єктивного контролю, при цьому найвищі показники інтернальності виявлені у реемігрантів $(6,56 \pm 2,28$ стенів) та емігрантів (6,13 $\pm 2,01$ стенів), у не емігрантів вони $€$

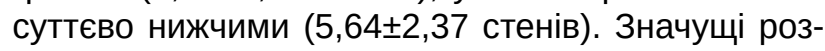
біжності виявлені при порівнянні груп реемігрантів та не емігрантів ( $p=0,025)$.

У сорері сімейних відносин емігранти виявляють ознаки інтернальності (6,05 $\pm 1,45$ стена), а реемігранти - екстернальності $(4,69 \pm 1,49)$; показники не емігрантів займають проміжне положення. Значущі розбіжності виявлені при порівнянні груп реемігрантів та не емігрантів $(p=0,006)$, емігрантів та реемігрантів $(p=0,001)$.

Аналогічні закономірності виявлені у сорері трудових відносин: показник інтернальності у емі-

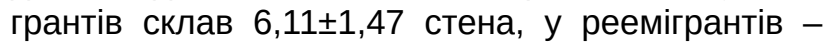

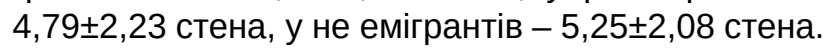
Значущі розбіжності виявлені при порівнянні груп емігрантів та не емігрантів ( $p=0,025)$, емігрантів та реемігрантів $(p=0,002)$.

У емігрантів, хворих на органічні депресивні розлади, виявлено інтернальний тип суб'єктивного контролю у сорері міжособистісних відносин (показник інтернальності у сорері міжособистісних відносин становить 6,08 1,87 стена), у реемігран-

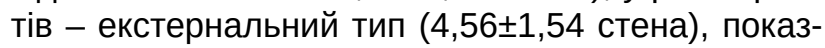
ник у не емігрантів займає проміжне положення,

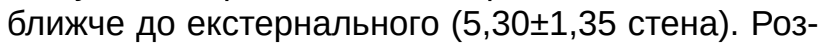
біжності значущі при порівнянні груп емігрантів та не емігрантів $(p=0,004)$, реемігрантів та не емігрантів $(p=0,005)$, емігрантів та реемігрантів $(p=0,001)$.

Показник інтернальності щодо здоров'я і хвороби у всіх досліджених груп відповідає інтернальному типу суб'єктивного контролю (у реемігрантів

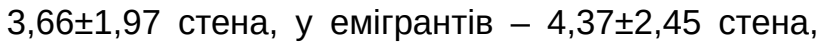

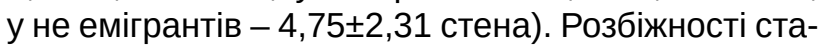
тистично значущі при порівнянні груп емігрантів та реемігрантів $(p=0,010)$.

\section{Висновки}

Таким чином, дослідження особливостей внутрішнього контролю у емігрантів та реемігрантів, хворих на депресивні розлади, у порівнянні 3 не емігрантами дозволило встановити ряд закономірностей впливу фактора еміграції: у цілому емігрантам притаманний високий, а реемігрантам низький рівень загальної інтернальності. Також у емігрантів виявлено високі показники інтернальності у сорері досягнень, сімейних відносин, трудових відносин, міжособистісних відносин. У реемігрантів виявлено ознаки екстернальності за цими сорерами, за винятком сорери невдач, де реемігранти виявляють ознаки інтернальності. Виявлені закономірності можуть бути пояснені як соціальнопсихологічними особливостями, так і особистісними характеристиками емігрантів та реемігрантів.

Основні перспективи подальших досліджень, на наш погляд, полягають у розробці лікувальнореабілітаційних та профрілактичних програм для лікування та профрілактики депресивних розладів у емігрантів та реемігрантів з урахуванням виявлених закономірностей.

\section{Список літератури}

1. Иванова М. В. Психическое здоровье мигрантов (клинический, социально-психологический и реабилитационный аспекты): дис... канд. мед. наук : 14.01.18 / Марина Владимировна Иванова; НИИ психического здоровья СО РАМН. Томск, 2007. - 205 с.

2. Кириленко Я. Интердисциплинарные аспекты миграции [Електронний ресурс] / Я. Кириленко, Е. Чуманская // Архів Національної бібліотеки ім. В. Вернадського. - 2011. - Т. 15, № 2 (55). - С. 52-53. - Режим доступу : http:// archive.nbuv.gov.ua/portal/chem_biol/Tzhp/2011_2/pdf/52-53.pdf. - Назва з екрану.

3. Міграція в Україні: фракти і цифреи / Міжнародна організація з міграції. - Київ : Представництво МОМ в Україні. - 2011. 4. Некоторые особенности психологической адаптации мигрантов [Электронный ресурс] / В. Б. Колянова, В.П.Боряк, Н.В.Барнаш,Л.В.Михайленко.-Режимдоступа:http://migrocenter.ru/publ/konfer/kavkaz/m_kavkaz030.php.Название с экрана.

5. Реан А. А. Практическая психодиагностика личности / А. А. Реан. - Санкт-Петербург : Изд-во Санкт-Петербургского ун-та, 2001. - 224 с.

6. Хармз В. А. Медико-психологические аспекты нарушения психической адаптации эмигрантов: дис... канд. психол. наук : 19.00.04 / Вахид Аблахад Хармз; Санкт-Петербургский гос. ун-т. - Санкт-Петербург, 2000. - 186 с. 
7. Щорічна Доповідь про стан дотримання та захисту прав і свобод людини в Україні Уповноваженого Верховної Ради України з прав людини: Постанова Верховної Ради України від 05.04.2011 року № 3194-VI // Голос України. 2011. - № 35. - C. 23-29.

8. Incidence of psychotic disorders in immigrant groups to the Netherlands / J. P. Selten, N. Veen, W. Feller [et al.] // British Journal of Psychiatry. - 2001. - № 178. - P. 367-372.

9. Lauber C. Patterns of Psychiatric Inpatient Care in Migrants: Results from Switzerland / C. Lauber, B. Lay, W. Rossler // Swiss Medical Weekly. - 2006. - № 135. - P. 50-56.

10. The mental health of migrants / B. E. Gavin, B. D. Kelly, A. Lane [et al.] // Irish Medical Journal. - 2001. - Vol. 94. P. 229-230.

\section{ОСОБЕННОСТИ СУБЪЕКТИВНОГО КОНТРОЛЯ У ЭМИГРАНТОВ И РЕЭМИГРАНТОВ, БОЛЬНЫХ ДЕПРЕССИВНЫМИ РАССТРОЙСТВАМИ}

О.П. Венгер

ГВУЗ «Тернопольский государственный медицинский университет им. И.Я. Горбачевского МЗ Украины», г. Тернополь, Украина

Цель: изучение особенностей субъективного контроля у эмигрантов и реэмигрантов, больных депрессивными расстройствами.

Материалы и методы. При помощи вопросника «Уровень субъективного контроля» и методики изучения ценностных ориентаций было обследовано 585 больных депрессивными расстройствами.

Результаты. Исследование особенностей субъективного контроля у 196 эмигрантов, 191 реэмигранта в сравнении с 198 не эмигрантами, больными разными формами депрессивных расстройств, показало большую выразительность общей интернальности у эмигрантов и меньшую - у реэмигрантов. При этом в ключевых сорерах достижений, семейных отношений, трудовых отношений, межличностных отношений эмигранты проявляют признаки интернальности, а реэмигранты - экстернальности. При этом для реэмигрантов характерен инфернальный тип субъективного контроля в сфере неудач. Выявленные закономерности могут объясняться как социально-психологическими особенностями, так и личностными характеристиками эмигрантов и реэмигрантов. Наиболее выразительные отличия выявлены у больных психогенными депрессивными расстройствами, в меньшей мере они выявляются у больных эндогенными и органическими депрессиями. Причины выявленных особенностей могут быть как в личностных особенностях эмигрантов и реэмигрантов, так и во влиянии объективных социально-психологических фракторов.

Выводы. Выявленные закономерности должны учитываться при разработке лечебно-реабилитационных и профилактических мероприятий.

КЛЮЧЕВЫЕ СЛОВА: эмигранты, реэмигранты, депрессивные расстройства, субъективный контроль.

\section{FEATURES OF SUBJECTIVE CONTROL IN EMIGRANTS AND REEMIGRANTS WITH DEPRESSIVE DISORDERS}

O.P. Venger

Ternopil State Medial University named by I.Ya. Horbachevsky, Ternopil, Ukraine

Aim: to study features of subjective control in emigrants and reemigrants with depressive disorders.

Materials and methods. Using questionary «Level of subjective control» and method of study of evaluative orientations were investigated 585 patients with depressive disorders.

Results. Commited study of features of subjective control in 196 emigrants, 191 reemigrants comparing with 198 not emigrants with different forms of depressive disorders, found more expressiveness of the internality in emigrants, less expressiveness in reemigrant. Herewith in main spheres of achievement, family relations, labor relations, interpersonal relations the emigrants show features of internality, and the reemigrants - of externality. Instead, reemigrants has internal type of of subjective control in failure sphere. The found features can be explained as social-psychological features and personal features of emigrants, and reemigrants. The most expressive differences found in patients with psychogenic depressive disordersвиявлені у хворих на психогенні депресивні розлади, less they can be identified in patients with with endogenic and organic depressions. The reasons of found features could be in personal features of emigrants and reemigrants and in influence of social-psychological factors.

Conclusions. Found features have to be considered in the development of treatment-rehabilitation and preventive measures.

KEY WORDS: emigrants, reemigrants, depressive disorders, subjective control.

Рукопис надійшов до редакції 10.09.2016 р.

\section{Відомості про автора:}

Венгер Олена Петрівна - к.мед.н., доц. кафедри неврології, психіатрії, наркології та медичної психології дВН3 «Тернопільський державний медичний університет ім. І.Я. Горбачевського»; тел. служб. : +38 (0352) 43-57-74. 